\title{
Questes
}

vestes Revue pluridisciplinaire d'études médiévales

\section{Violences médiévales : avant-propos}

\section{Dominique Barthélemy}

\section{(2) OpenEdition}

\section{Journals}

\section{Édition électronique}

URL : http://journals.openedition.org/questes/343

DOI : 10.4000/questes.343

ISSN : 2109-9472

\section{Éditeur}

Les Amis de Questes

\section{Édition imprimée}

Date de publication : 15 mars 2008

Pagination : 1

ISSN : 2102-7188

\section{Référence électronique}

Dominique Barthélemy, «Violences médiévales : avant-propos », Questes [En ligne], 14 | 2008, mis en ligne le 01 janvier 2014, consulté le 23 septembre 2020. URL : http://journals.openedition.org/ questes/343; DOI : https://doi.org/10.4000/questes.343 


\section{Avant-propos}

Longtemps, l'époque médiévale a été comme le faire-valoir, par sa violence apparemment irrépressible et sans entraves, de l'empire romain qui l'avait précédée, et surtout de l'État moderne, tous deux passant pour plus justes et pacificateurs. Aujourd'hui, l'analyse des codes des limites de ses violences mène les médiévistes à des descriptions plus variées, à des récits plus intéressants, à des commentaires plus nuancés. Les contributions rassemblées ici en donneront au lecteur un aperçu particulièrement significatif, centré sur les derniers siècles médiévaux, en le promenant de la Scandinavie à la Toscane. La littérature et l'archéologie s'associent ici aux dossiers d'archives pour nourrir l'étude et la réflexion, et Léonard Dauphant introduit et conclue avec maestria.

Un historien qui s'est souvent employé, à l'aide des apports de l'anthropologie de la vengeance, à démystifier la violence des sociétés franque et féodale, ne peut que lire avec passion ces textes très suggestifs et souhaiter que leurs auteurs poursuivent tous d'un bon pas leur quête d'une histoire médiévale toujours plus exacte et plus riche. 